\title{
Mild and Selective Silicon-mediated access to enantioenriched 1,2-mercaptoamines and $\beta$-amino arylchalcogenides
}

\author{
Damiano Tanini,* Cosimo Borgogni and Antonella Capperucci* \\ Metal-free ring opening reactions of activated and unactivated aziridines with different silyl chalcogenides are described. \\ Judicious tuning of the reaction conditions enables the synthesis of chiral enantioenriched $\mathrm{N}$-Ts and $\mathrm{N}$-Boc 1,2- \\ mercaptoamines in good yields from the corresponding aziridines and bis(trimethylsilyl)sulfide. $\mathrm{N}$-Protected and $\mathrm{N}-\mathrm{H}$ \\ unactivated aziridines are efficiently converted into the corresponding $\beta$-arylchalcogeno amines upon treatment with \\ suitable arylchalcogenosilanes. The silicon-mediated ring opening reactions proceed with excellent regioselectivity and \\ stereospecificity, allowing to access a wide array of synthetically and biologically valuable enantioenriched \\ chalcogenoamines.
}

\section{Introduction}

Chalcogenoamines (chalcogens $\mathrm{S}, \mathrm{Se}, \mathrm{Te}$ ) are important and versatile organic compounds. Among the variety of these molecules, $\beta$-aminothiols represent arguably the most important class. They are ubiquitous motifs in naturally occurring molecules (i.e., penicillamine, cysteine, cysteamine, glutathione), pharmaceuticals (i.e., enzyme inhibitors, ${ }^{1}$ radioprotective agents ${ }^{2}$ ), and materials. $\beta$-Aminothiols find wide application in synthetic organic chemistry, medicinal chemistry, and catalysis. ${ }^{3}$ They are commonly used as intermediates for the synthesis of biologically relevant molecules, such as peptides, ${ }^{4}$ thiazolidines, ${ }^{5}$ thiazolines, ${ }^{6}$ thiomorpholines, ${ }^{7}$ and thiazepines. ${ }^{8}$

Several methods for the synthesis of $\beta$-aminothiols have been reported, ${ }^{9}$ including the multistep conversion of aminoalcohols and aminoacids into the corresponding thiols, commonly achieved by nucleophilic substitution ${ }^{10}$ or by Mitsunobu reaction. ${ }^{11}$ Alternatively, $\beta$-aminothiols can be obtained through nucleophilic ring opening reactions (NROR) of threeand five-membered heterocycles, such as aziridines, ${ }^{12}$ sulfamidates, ${ }^{13}$ thiazolidinones, ${ }^{14}$ and thiazolidines ${ }^{15}$ with a diverse array of sulfurated nucleophiles. Aminoethanethiols can also be synthesized by ring opening of thiiranes with amines. ${ }^{16}$ To the best of our knowledge, most of these procedures involve multistep sequences and all share a final deprotection or reduction step necessary to obtain the free thiol moiety.

However, despite a number of methods have been described for the synthesis of $\beta$-aminothiols, the development of a general and mild route to directly access these compounds, without requiring a further deprotection of the thiol functionality, remains challenging and highly desirable.
Besides $\beta$-aminothiols, also $\beta$-arylchalcogeno amines respresent versatile molecules in biology ${ }^{17}$ and in synthesis and, for these reasons, have attracted considerable interest. $\beta$ aminochalcogenides find wide application as valuable synthetic intermediates and as chiral ligands in asymmetric reactions. ${ }^{18}$ For example, chiral $\beta$-aminosulfides bearing a free amino group have been used as ligands in Ir-catalyzed asymmetric transfer hydrogenation of prochiral ketones ${ }^{19}$ and in asymmetric epoxidation reactions of aldehydes. ${ }^{20}$ Furthermore, chiral $\beta$-aminosulfides have been employed for the synthesis of sulfoxide-Shiff base ligands for Cu-catalyzed asymmetric Henry reactions ${ }^{21}$ and for the preparation of hybrid $P, S$ ligands for asymmetric Pd-catalyzed decarboxilative $[4+2]$ cycloadditions. $^{22}$

$\beta$-Arylchalcogeno amines are commonly prepared by ring opening reactions of aziridines, ${ }^{23} \beta$-lactones ${ }^{24}$, and cyclic sulfamidates, ${ }^{25}$ by nucleophilic substitution, ${ }^{26}$ and by reaction of olefins with benzeneselenenyl chloride and amines. ${ }^{27}$

However, although several methods have been reported for the preparation of $N$-protected $\beta$-arylchalcogeno amines, only a relatively limited number of procedures have been reported for the synthesis of more useful analogues bearing a free amino functionality. Furthermore, whilst $\beta$-aminosulfides have been deeper studied, the related selenium- and telluriumcontaining derivatives have received less attention. In addition, only a few examples of NRORs of $\mathrm{N}$-H unactivated aziridines with chalcogen-containing nucleophiles have been reported. ${ }^{23 a, b, e, f}$ In this context, whilst silylated nucleophiles have been used in nucleophilic ring opening reactions of $\mathrm{N}$ protected aziridines, ${ }^{28}$ to the best of our knowledge their reactivity with the unactivated $\mathrm{N}-\mathrm{H}$ analogues has never been reported.

We recently reported alternative approaches to functionalized sulfur-, selenium-, and tellurium-containing compounds, 
proceeding through the silicon-mediated regioselective ring opening reaction of strained heterocycles. ${ }^{29}$ We recognized that the extension of this reactivity to $\mathrm{N}$-protected or $\mathrm{N}-\mathrm{H}$ aziridines and suitable silyl chalcogenides could provide a novel method to access $\beta$-aminothiols and $\beta$-arylchalcogeno amines.

In this communication, we report the effective development of a new procedure in which $\mathrm{N}$-activated aziridines are conveniently converted into 1,2-mercaptoamines and $\beta$ arylchalcogeno amines upon reaction with bis(trimethylsilyl)sulfide and (phenylchalcogeno)trimethylsilane, respectively. Furthermore, the study of the first NROR example of $\mathrm{N}-\mathrm{H}$ aziridines with silyl chalcogenides led to disclose an alternative direct route to $\beta$ arylchalcogenoamines bearing a free amino function.

\section{Results and discussion}

We began our investigations by establishing the optimal conditions required to obtain the $N$-tosyl 1,2-mercaptoamine 3a from the corresponding enantioenriched $N$-Tosyl protected aziridine $\mathbf{1 a}$, easily synthesized from L-phenylalanine through a reported procedure, ${ }^{30}$ and bis(trimethylsislyl)sulfide (HMDST) 2. On the basis of previous results related to the ring opening of epoxides and thiiranes with thiosilanes, two different catalysts such as $\mathrm{PhONBu}_{4}{ }^{31}$ and $\operatorname{TBAF}^{28 a, b, 29}$ were evaluated in order to functionalize the S-Si bond and promote the desired transformation. Aziridine 1a was therefore treated with $\left(\mathrm{Me}_{3} \mathrm{Si}\right)_{2} \mathrm{~S} 2$ at room temperature in the presence of $10 \mathrm{~mol} \%$ of $\mathrm{PhONBu}_{4}$ (Table 1, entry 1); under these conditions, the desired $\beta$-aminothiol $\mathbf{3 a}$ was achieved, albeit together with an almost equimolar amount of the corresponding disulfide 4a. Taking advantage of our recent findings in the synthesis of labile selenols, ${ }^{32}$ we next evaluated the effect of reaction time, the reaction temperature, and amount of catalyst on the 3a:4a ratio. When reaction temperature and reaction time were decreased $\left(0^{\circ} \mathrm{C}\right.$ for $5 \mathrm{~min}$, Table 1, entry 2), the ratio between 3a and $4 \mathbf{a}$ resulted improved, although a poor conversion was achieved (ca. $35 \%$ of the aziridine 1 a remained unreacted). Nonetheless, using $20 \mathrm{~mol} \%$ of $\mathrm{PhONBu}_{4}$ and performing the reaction at $0^{\circ} \mathrm{C}$ for $10 \mathrm{~min}$, a good thiol vs disulfide selectivity (90:10) and an excellent conversion were obtained (Table 1, entry 3).

Having explored the $\mathrm{PhO}^{-}$-induced ring opening of aziridines with HMDST, we turned our attention on the evaluation of the $\mathrm{F}^{-}$catalyzed reaction. Aziridine 1a was initially treated with $\mathbf{2}$ at room temperature in the presence of $20 \mathrm{~mol} \%$ of TBAF until complete consumption of the substrate (Table 1, entry 4). However, although a silicon mediated ring opening reaction readily occurred, under these conditions the desired $\beta$ aminothiol 3a was not isolated, being the corresponding disulfide $4 \mathbf{a}$ the main reaction product. Intriguingly, we also noticed the formation of ca. $20 \%$ of the sulfide, arising from the nucleophilic attack of the thiol (or the thiosilane intermediate) onto a second molecule of aziridine. The effect of reaction time, reaction temperature, and amount of catalyst was then evaluated. We found that just reducing the reaction time to $5 \mathrm{~min}$, the 3a:4a ratio increased to 65:35 (Table 1, entry 5) maintaining a high conversion; under these conditions, the use of a lower amount of TBAF led to a poor conversion (35\% of starting aziridine remained unreacted), whilst the 3a:4a ratio was only slightly improved (Table 1, entry 6). On the other hand, we were delighted to find that performing the reaction at $0^{\circ} \mathrm{C}$ for $10 \mathrm{~min}$ in the presence of 10 mol\% of TBAF, the desired 1,2-mercaptoamine 3a was smoothly formed in excellent yield and, as observed for all these NRORs, with complete regioselectivity (Table 1, entry 7).

Table 1: Optimization of the reaction conditions

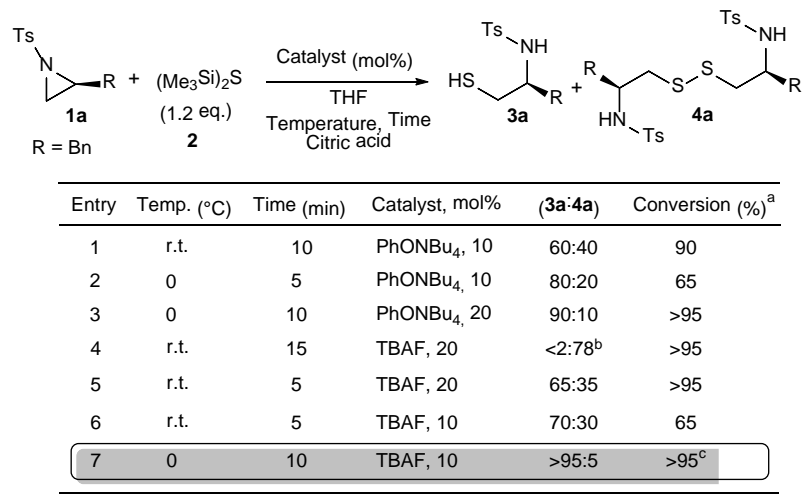

${ }^{a}$ Conversion was determined by ${ }^{1} \mathrm{H}$ NMR; ${ }^{b}$ ca. $20 \%$ of the corresponding sulfide was formed; ${ }^{c} 92 \%$ yield.

Having established optimal conditions for the effective synthesis of 1,2-mercaptoamines, we next explored the scope of this procedure. Thus, differently $\mathrm{N}$-protected aziridines, conveniently prepared from the corresponding natural aminoacids (L-Phe, L-Ala, L-Val, LIle, L-Leu), were treated with $\left(\mathrm{Me}_{3} \mathrm{Si}\right)_{2} \mathrm{~S}$ as reported in the Scheme 1.

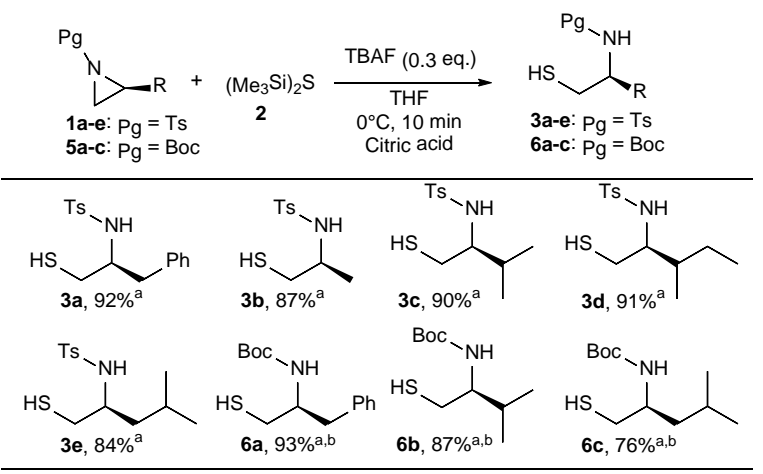

${ }^{a}$ Yield refers to isolated product; ${ }^{b}$ Ring opening reaction carried out at r.t., for $1 \mathrm{~h}$, in the presence of 1.0 eq. of TBAF.

Scheme 1. Scope of the synthesis of 1,2-mercaptoamines through the ring opening of aziridines with HMDST

Variously substituted enantioenriched $N$-tosyl aziridines 1a-e were smoothly converted into the corresponding 1,2mercaptoamines 3a-e in very good yields (Scheme 1). Furthermore, the reaction was also amenable to $N$-Boc 
protected aziridines; optically pure $N$-Boc $\beta$-aminothiols 6a-c were easily achieved from $\mathbf{5 a - c}$ under slightly modified reaction conditions. Indeed, $\mathrm{N}$-Boc aziridines proved to be less reactive with respect to the $N$-Tosyl analogues ${ }^{23 f}$ and, therefore, the ring opening reaction was carried out at ambient temperature in the presence of 1.0 eq. of TBAF (Scheme 1). All the synthesized 1,2-mercaptoamines arose from a clean nucleophilic attack of the sulfur atom on the less hindered side of the three-membered ring. ${ }^{33}$

Having successfully developed a convenient procedure for the synthesis of 1,2 mercaptoamines, we then evaluated the use of aromatic silyl chalcogenides to access $\beta$-phenylchalcogeno amines. As stated above, chiral $\beta$-arylchalcogeno amines represent an interesting class of compounds and the study of an alternative, general and mild methodology for their synthesis would be desirable.

Thus, in order to evaluate a novel silicon-mediated route to this class of compounds, we investigated the reactivity of silyl chalcogenides $\mathbf{7 a - c}$ with aziridines $\mathbf{1 a}$ and $\mathbf{5 a}$. As reported in the Scheme 2 , in the presence of a catalytic amount of TBAF, the phenylthio, phenylseleno, and phenyltelluro moieties were smoothly transferred onto the aziridine, leading smoothly to the formation of $N$-protected $\beta$-phenylchalcogeno amines $8 \mathrm{a}-\mathrm{c}$ and $\mathbf{9 a - c}$ in good yields.

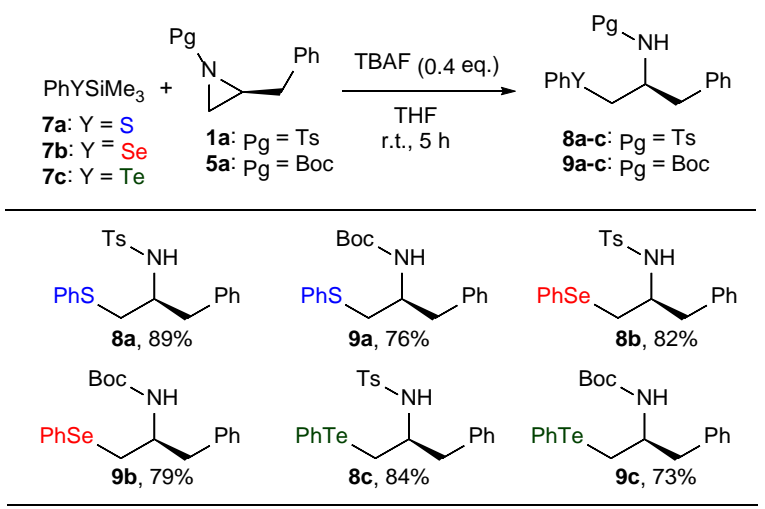

Scheme 2. Reactivity of PhSSiMe $3, \mathrm{PhSeSiMe}_{3}$, and $\mathrm{PhTeSiMe}_{3}$ with $\mathrm{N}$-protected aziridines.

Having demonstrated that $N$-Tosyl and $N$-Boc aziridines could be reacted with silyl chalcogenides to afford the corresponding arylchalcogeno amines, we wished to extend this reactivity to $\mathrm{N}-\mathrm{H}$ unactivated aziridines. ${ }^{34}$ We were pleased to find that $\mathrm{PhSSiMe}_{3} \mathrm{7a}$ reacted with benzyl-, methyl-, and isopropyl-substituted unprotected aziridines $10 \mathrm{a}-\mathrm{c}$ to give the corresponding phenylsulfides 11aa-11ac, bearing free $\mathrm{NH}_{2}$ groups (Scheme 3). Furthermore, the related selenosilane $\mathbf{7 b}$ and tellurosilane $\mathbf{7 c}$ could be successfully employed in this reaction, allowing to directly access unprotected $\beta$-amino- selenides and tellurides $\mathbf{1 1} \mathbf{b a - 1 1} \mathbf{b c}$ and $\mathbf{1 1} \mathrm{ca}-$ $11 c c$, respectively, without requiring further deprotection steps ${ }^{26 a, 35}$ (Scheme 3).

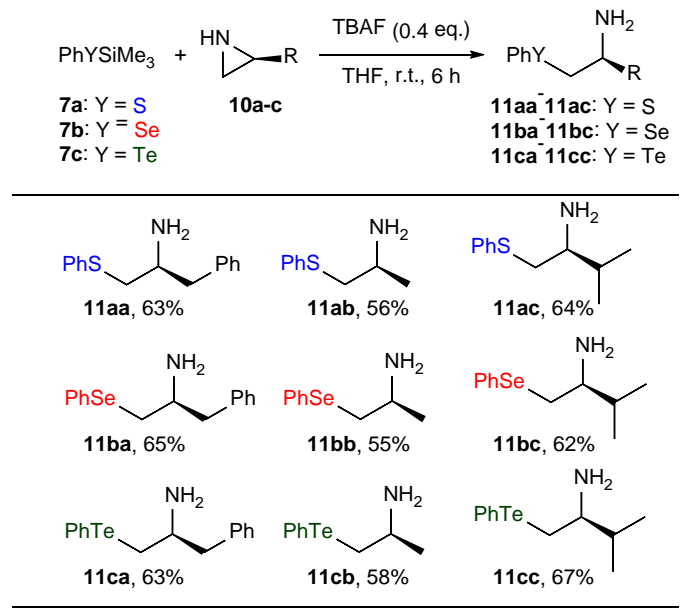

Scheme 3. Reactivity of $\mathrm{PhSSiMe}_{3}, \mathrm{PhSeSiMe}_{3}$, and PhTeSiMe ${ }_{3}$ with unprotected aziridines.

Furthermore, to demonstrate the possibility to apply this procedure to differently substituted silyl chalcogenides, arylseleno- and aryltelluro amines $\mathbf{1 3 a}$ and $\mathbf{1 3 b}$ were successfully obtained by reaction of $p$-tolylselenosilane $\mathbf{1 2 a}$ and $p$-tolyltellurosilane $\mathbf{1 2 b}$ with the unprotected aziridine $\mathbf{1 0 b}$ in the presence of a catalytic amount of TBAF (Scheme 4), thus illustrating the versatility of the methodology.

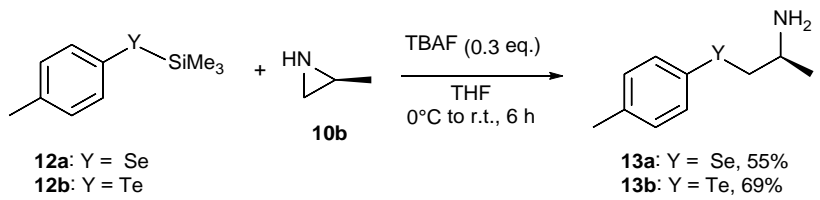

Scheme 4. Synthesis of aminoselenide 13a and aminotelluride $13 b$.

The methodology here developed is also important in order to straightforwardly access small molecules with catalytic antioxidant activity. Indeed, $\beta$-phenylseleno- and $\beta$ phenyltelluro-amines bearing a free amino function behave as much more active glutathione peroxidase mimics with respect to their $N$-Tosyl protected analogues. ${ }^{35}$

\section{Conclusions}

In conclusion, we have developed a novel, mild, convenient procedure to access chiral enantioenriched $\beta$-aminothiols through the ring opening reaction of $N$-Ts and $N$-Boc aziridines with bis(trimethylsilyl)sulfide. N-Activated aziridines were also successfully employed in reactions with arylchalcogenosilanes, enabling the synthesis of $\mathrm{N}$-protected enantioenriched arylchalcogenoamines. Furthermore, the reaction of $\mathrm{N}-\mathrm{H}$ unactivated aziridines with silyl chalcogenides has been for the first time investigated, leading to unveil a new protocol for the synthesis of arylchalcogenoamines bearing a free amino function.

The reactions proceed via fluoride or phenoxide ion-induced functionalization of silyl chalcogenides, providing a stereospecific 
and highly regioselective access to variously substituted aminochalcogenides.

\section{Experimental}

\section{General}

All reactions were carried out in an oven-dried glassware under inert atmosphere $\left(\mathrm{N}_{2}\right)$. Solvents were dried using a solvent purification system (Pure-Solv ${ }^{\mathrm{TM}}$ ). All commercial materials were purchased from various commercial sources and used as received, without further purification. $\mathrm{N}-\mathrm{Ts},{ }^{1} \mathrm{~N}-\mathrm{Boc},{ }^{2} \mathrm{~N}-\mathrm{H}^{3}$ aziridines and silyl chalcogenides ${ }^{4}$ were prepared according to literature reported procedures.

Flash column chromatography purifications were performed with Silica gel 60 (230-400 mesh). Thin layer chromatography was performed with TLC plates Silica gel $60 \mathrm{~F}_{254}$, which was visualised under UV light, or by staining with an ethanolic acid solution of $p$ anisaldehyde followed by heating. High resolution mass spectra (HRMS) were recorded by Electrospray Ionization (ESI). GC-MS was performed on a Varian CP 3800/Saturn 2200 instrument.

${ }^{1} \mathrm{H}$ and ${ }^{13} \mathrm{C}$ NMR spectra were recorded in $\mathrm{CDCl}_{3}$ using Mercury 400, Bruker 400 Ultrashield, and Varian Gemini 200 spectrometers operating at $400 \mathrm{MHz}$ and $200 \mathrm{MHz}\left(\right.$ for ${ }^{1} \mathrm{H}$ ), $100 \mathrm{MHz}$ and $50 \mathrm{MHz}$ (for ${ }^{13} \mathrm{C}$ ). ${ }^{77} \mathrm{Se}$ NMR spectra were recorded using Bruker 400 Ultrashield and Varian Gemini 200 spectrometers, operating at 76 $\mathrm{MHz}$ and $38 \mathrm{MHz}$, respectively. ${ }^{125} \mathrm{Te}$ NMR spectra were recorded in $\mathrm{CDCl}_{3}$ at $126 \mathrm{MHz}$ with a Bruker Ultrashield 400 Plus instrument. NMR signals were referenced to nondeuterated residual solvent signals $\left(\mathrm{CDCl}_{3}\right.$ : $7.26 \mathrm{ppm}$ for ${ }^{1} \mathrm{H}, 77.0 \mathrm{ppm}$ for $\left.{ }^{13} \mathrm{C}\right)$. Diphenyl diselenide $(\mathrm{PhSe})_{2}$ was used as an external reference for ${ }^{77} \mathrm{Se}$ NMR $(\delta=461 \mathrm{ppm})$. (PhTe $)_{2}$ was used as an external reference for ${ }^{125} \mathrm{Te}$ $(\delta=420 \mathrm{ppm})$. Chemical shifts $(\delta)$ are given in parts per million (ppm), and coupling constants $(J)$ are given in Hertz $(\mathrm{Hz})$, rounded to the nearest $0.1 \mathrm{~Hz} .{ }^{1} \mathrm{H}$ NMR data are reported as follows: chemical shift, integration, multiplicity $(s=$ singlet, $d=$ doublet, $t=$ triplet, ap $\mathrm{d}=$ apparent doublet, $\mathrm{m}=$ multiplet, $\mathrm{dd}=$ doublet of doublet, $\mathrm{bs}=$ broad singlet, $b d=$ broad doublet, ecc.), coupling constant $(J)$ or line separation (Is), and assignment. Where reported, NMR assignments are made according to spin systems, using, where appropriate, APT and 2D NMR experiments (COSY, HSQC) to assist the assignment.

Naming of Compounds. Compound names are those generated by ChemBioDraw 15.0 software (PerkinElmer), following IUPAC nomenclature.

General Procedure for the synthesis of $\boldsymbol{N}$-Tosyl $\boldsymbol{\beta}$-aminothiols 3a-e. A solution of $N$-Tosyl aziridine 1 (0.5 mmol, 1.0 eq.) and bis(trimethylsilyl)sulfide (HMDST, 2) $(0.6 \mathrm{mmol}, 1.2$ eq.) in dry THF $(2 \mathrm{~mL})$ was cooled under inert atmosphere at $0^{\circ} \mathrm{C}$, and treated with TBAF $(0.12 \mathrm{~mL}$ of $1 \mathrm{M}$ THF solution, $0.12 \mathrm{mmol})$. The reaction was stirred for $10 \mathrm{~min}$ and then citric acid (50\% aq solution) was added. Afterwards, the mixture was diluted with diethyl ether, washed with water, and dried over $\mathrm{Na}_{2} \mathrm{SO}_{4}$. The solvent was evaporated under vacuum affording $N$-Tosyl $\beta$-aminothiols 3a-e pure enough to be used without further purification.
General procedure for the synthesis of $\boldsymbol{N}$-Boc $\boldsymbol{\beta}$-aminothiols $6 \mathrm{a}-\mathrm{c}$. A solution of aziridine $5 \quad(0.5 \quad \mathrm{mmol}, 1.0 \quad$ eq. $)$ and bis(trimethylsilyl)sulfide (HMDST, 2) $(0.6 \mathrm{mmol}, 1.2$ eq.) in dry THF (3 $\mathrm{mL})$ was treated with TBAF $(0.6 \mathrm{~mL}$ of $1 \mathrm{M}$ THF solution, 1.2 $\mathrm{mmol})$. The reaction was stirred at room temperature for $1 \mathrm{~h}$ and then citric acid (50\% aq solution) was added. Afterwards, the mixture was diluted with diethyl ether, washed with water, and dried over $\mathrm{Na}_{2} \mathrm{SO}_{4}$. The solvent was evaporated under vacuum affording the desired $N$-Boc $\beta$-aminothiols 6a-c pure enough to be used without further purification.

General procedure for the synthesis of $\beta$-phenylchalcogenoamines by NRORs of aziridines with phenylchalcogeno silanes. A solution of aziridine (1, $\mathrm{N}$-Ts aziridine; 5, $\mathrm{N}$-Boc aziridine or 10, $\mathrm{N}$-H aziridine) (0.5 mmol, 1.0 eq.) and phenylchalcogeno silane (7a, $\mathrm{PhSSiMe}_{3} ; \mathbf{7 b}$, $\mathrm{PhSeSiMe}_{3} ; 7 \mathrm{c}, \mathrm{PhTeSiMe}_{3}$ ) (0.6 mmol, 1.2 eq.) in dry THF (3 mL) was treated with TBAF $(0.24 \mathrm{~mL}$ of $1 \mathrm{M}$ THF solution, $0.24 \mathrm{mmol})$. The reaction was stirred at room temperature for 5-6 $h$, until complete consumption of starting material was observed by TLC. Afterwards, $\mathrm{NH}_{4} \mathrm{Cl}$ (sat. $a q$ solution) was added, the mixture was diluted with diethyl ether, washed with water, and dried over $\mathrm{Na}_{2} \mathrm{SO}_{4}$. The solvent was evaporated under vacuum and the crude material was purified by flash column chromatography to afford ?phenylchalcogenoamines $\mathbf{8 , 9}$ or $\mathbf{1 1}$.

\section{Conflicts of interest}

There are no conflicts to declare.

\section{Notes and references}

1 (a) J. D. Park and D. H.Kim, J. Med. Chem., 2002, 45, 911; (b) H. Chen, B. P. Roques and M. C. Fournié-Zaluski, Bioorg. Med. Chem. Lett., 1999, 9, 1511; (c) L. Martin, F. Cornille, P. Coric, B. P. Roques and M. C. Fournié-Zaluski, J. Med. Chem., 1998, 41, 3450.

2 P. Auzeloux, J. Papon, R. Pasqualini and J. C.Madelmont, J. Med. Chem., 2001, 44, 1116.

3 A. L. Braga, F. Z. Galetto, O. E. D. Rodrigues, C. C. Silveira andM. W. Paixão, Chirality, 2008, 20, 839. For a review see: M. Mellah, A. Voituriez and E. Schultz, Chem. Rev., 2007, 107, 5133

4 (a) L. Hu, H. Zhu, D. Du-Ming and J. Xu, J. Org. Chem., 2007, 72, 4543; (b) D. Hesek, M. Toth, V. Krchnak, R. Fridman and S. Mobashery, J. Org. Chem., 2006, 71, 5848; (c) S. Mourtas, C. Katakalou, A. Nicolettou, C. Tzavara, D. Gatos and K. Barlos, Tetrahedron Lett., 2003, 44, 179.

5 (a) D. Tanini, G. Barchielli, F. Benelli, A. Degl'Innocenti and A. Capperucci, Phosphorus Sulfur Silicon Relat. Elem., 2015, 190, 1265; (b) C. Gros, C. Boulègue, N. Galeotti, G. Niel and P. Jouin, Tetrahedron, 2002, 58, 2673.

6 For a review see: A. C. Gaumont, M. Gulea and J. Levillain, Chem. Rev., 2009, 109, 1371 and references cited therein.

7 (a) O. A. Attanasi, P. Filippone, S. Lilliani, F. Mantellini, S. Nicolini, J. M. de los Santos, R. Ignacio, D. Aparicio and F. Palacios, Tetrahedron, 2008, 64, 9264; (b) G. Ziakas, E. A. Rekka, A. M. Gavalas, P. T. Eleftheriou and P. N. Kourounakis, Bioorg. Med. Chem., 2006, 14, 5616; (c) M. T. Gallego, E. Brunet and J. L. Garcia Ruano, J. Org. Chem., 1993, 58, 3905.

8 Inter alia: (a) J. Drewe, S. Kasibhatla, B. Tseng, E. Shelton, D. Sperandio, R. M. Yee, J. Litvak, M. Sendzik, J. R. Spencer and 
S. X. Cai, Bioorg. Med. Chem. Lett., 2007, 17, 4987; (b) J. I. Trujillo, H. C. Huang, W. L. Neumann, M. W. Mahoney, S. Long, W. Huang, D. J. Garland, C. Kusturin, Z. Abbas, M. S South and D. B. Reitz, Bioorg. Med. Chem. Lett., 2007, 17, 4568.

9 For a review see: G. Mercey, V. Reboul, M. Gulea, J. Levillain, and C. Gaumont, Eur. J. Org. Chem., 2012, 5423.

10 (a) V. V. Sureshbabu, T. M. Vishwanatha and B. Vasantha, Synlett, 2010, 1037; (b) S. L. Tseng and T. K. Yang, Tetrahedron: Asymmetry, 2005, 16, 773; (c) G. A. Cran, C. L. Gibson and S. Handa, Tetrahedron: Asymmetry, 1995, 6, 1553.

11 V. T. Myllymäki, M. K. Lindvall and A. M. P. Koskinen, Tetrahedron, 2001, 57, 4629.

12 Inter alia: (a) J. Y. Wu, Z. B. Luo, L. X. Dai and X. L. Hou, J. Org. Chem., 2008, 73, 9137; (b) D. Sureshkumar, T. Gunasundari, V. Ganesh and S. Chandrasekaran, J. Org. Chem., 2007, 72, 2106; (c) L. Hu, H. Zhu, D. M. Du and J. Xu, J. Org. Chem., 2007, 72, 4543; (d) S. Fanjul, A. N. Hulme and J. W. White, Org. Lett., 2006, 8, 4219; (e) D. Rosenthal, G. Brandruf, K. H. Davis, J. Wall and M. E. Wall, J. Org. Chem., 1965, 30, 3689.

13 R. B. Nasir Baig, N. Y. Phani Kumar, J. Mannuthodikayil and S. Chandrasekaran, Tetrahedron, 2011, 67, 3111.

14 M. Yamakuchi, H. Matsunaga, R. Tokuda, T. Ishizuka and M. Nakajima, T. Kunieda, Tetrahedron Lett., 2005, 46, 4019.

15 H. Yang, X. C. Sheng, E. M. Harrington, K. Ackermann, A. M. Garcia and M. D. Lewis, J. Org. Chem. 1999, 64, 242.

16 (a) J. Harfouche, D. Hérault, M. L. Tommasino, S. PelletRostaing and M. Lemaire, Tetrahedron: Asymmetry, 2004, 15, 3413; (b) M. Taddei, A. Papini, M. Fiorenza and A. Ricci, Tetrahedron Lett., 1983, 24, 2311.

17 Inter alia: (a) A. Angeli, D. Tanini, A. Capperucci and C. T. Supuran, Bioorg. Chem., 2018, 76, 268; (b) A. Angeli, D. Tanini, A. Capperucci, G. Malevolti, F. Turco, M. Ferraroni, C. T. Supuran, Bioorg. Chem., 2018, 81, 642; (c) A. Angeli, D. Tanini, A. Capperucci and C. T. Supuran, ACS Med. Chem. Lett., 2017, 8, 1213; (d) D. Tanini, V. D'Esopo, D. Chen, G. Barchielli and A. Capperucci, Phosphorus, Sulfur Silicon Relat. Elem., 2017, 192, 166.

18 (a) A. Alcaide and A. Llebaria, Tetrahedron Lett., 2012, 53, 2137; (b) M. V. Voronkov, R. C. Kanamarlapudi and P. Richardson, Tetrahedron Lett., 2005, 46, 6907; (c) S. berlin, C. Ericsson and L. Engman, J. Org. Chem., 2003, 68, 8386.

19 (a) J. K. Ekegren, P. Roth, K. Källström, T. Tarnai and P. G. Andersson, Org. Biomol. Chem., 2003, 1, 358; (b) D. G. I. Petra, P. C. J. Kamer, A. L. Spek, H. E. Schoemaker and P. W. N. M. van Leeuwen, J. Org. Chem., 2000, 65, 3010.

20 (a) M. Namutebi, E. M. McGarrigle and V. K. Aggarwal, Phosphorus, Sulfur, and Silicon 2010, 185, 1250; (b) V. K. Aggarwal, E. M. McGarrigle and M. A. Shaw in Science of Synthesis, Stereoselective Synthesis 2, ed. G. A. Molander, George Thieme Verlag, 2010, 311.

21 (a) L. Y. Chen, J. R. Chen, H. G. Cheng, L. Q. Lu and W. J. Xiao, Eur. J. Org. Chem., 2014, 4714; (b) H. G. Cheng, L. Q. Lu, T. Wang, J. R. Chen and W. J. Xiao, Chem. Commun., 2012, 48 5596.

22 Y. Wei, L. Q. Lu, T. R. Li, B. Feng, Q. Wang, W. J. Xiao and H. Alper, Angew. Chem. Int. Ed., 2016, 55, 2200.

23 (a) J. Luginina and M. Turks, Synlett, 2017, 28, 939; (b) P. C. Silva, E. L. Borges, D. B. Lima, R. G. Jacob, E. J. Lenardão, G. Perin and M. S. Silva, Arkivoc, 2016, 5, 376; (c) M. Senatore, A. Lattanzi, S. Santoro, C. Santi and G. Della Sala, Org. Biomol. Chem., 2011, 9, 6205; (d) B. Movassagh and E. S. Morovat, J. Sulfur Chem., 2011, 32, 117; (e) S. M. Salman, R. S. Schwab, E. E. Alberto, J. Vargas, L. Dornelles, O. E. D. Rodrigues and A. L. Braga, Synlett, 2011, 69; (f) A. L. Braga, R. S. Schwab, E. E. Alberto, S. M. Salman, J. Vargas and J. B.
Azeredo, Tetrahedron Lett., 2009, 50, 2309; (g) V. Ganesh and S. Chandrasekaran, Synthesis, 2009, 3267.

24 A. Schneider, O. E. D. Rodrigues, M. W. Paixão, H. R. Appelt, A. L. Braga and L. A. Wessjohann, Tetrahedron Lett., 2006, 47, 1019.

25 C. Venkateswarlu, B. Datta and S. Chandrasekaran, RSC Adv., 2014, 4, 42952.

26 (a) H. R. Rajegowda, P. R. Kumar, A. Hosamani and R. J. Butcher, New. J. Chem., 2018, 42, 6264; (b) R. H. Revanna, R. P. Kumar, A. Hosamani and P. B. Siddagangaiah, J. Organomet. Chem., 2015, 799-800, 61.

27 27. Boivin, S.; Outurquin, F.; Paulmier, C. Tetrahedron Lett., 2000, 41, 663 .

28 (a) D. Tanini, A. Capperucci and A. Degl'Innocenti, Eur. J. Org. Chem,. 2015, 357; (b) A. Capperucci and D. Tanini, Phosphorus Sulfur Silicon Relat. Elem., 2015, 190, 1320; (c) S. Nakamura, M. Hayashi, Y. Kamada, R. Sasaki, Y. Hiramatsu, N. Shibata and T. Toru, Tetrahedron Lett., 2010, 51, 3820; (d) S. Minakata, Y. Okada, Y.Oderaotoshi and M. Komatsu, Org. Lett., 2005, 7, 3509; (e) J. Wu, X. L. Hou and L. X. Dai, J. Org. Chem., 2000, 65, 1344.

29 (a) D. Tanini, A. Grechi, S. Dei, E. Teodori and A. Capperucci, Tetrahedron, 2017, 73, 5646; (b) A. Capperucci, D. Tanini, C. Borgogni and A. Degl'Innocenti, Heteroatom Chem., 2014, 25, 678; (c) A. Degl'Innocenti, A. Capperucci, A. Cerreti, S. Pollicino, S. Scapecchi, I. Malesci and G. Castagnoli, Synlett 2005, 3063 .

30 M. B. Bieber and M. C. F. de Araujo, Molecules, 2002, 7, 902.

31 (a) A. Capperucci, C. Tiberi, S. Pollicino and A. Degl'Innocenti, Tetrahedron Lett., 2009, 50, 2808; (b) M. Michida and T. Mukaiyama, Chem. Lett., 2008, 37, 26; (c) M. Michida and T. Mukaiyama, Chem. Asian J., 2008, 3, 1592.

32 (a) D. Tanini, C. Tiberi, C. Gellini, P. R. Salvi, A. Capperucci, Adv, Synth. Catal., 2018, 360, 3367; (b) A. Angeli, D. Tanini, A. Nocentini, A. Capperucci, M. Ferraroni, P. Gratteri and C.T. Supuran, Chem. Commun., 2019, 55, 648.

33 All the obtained 1,2-mercaptoamines were isolated pure enough to be used without requiring further purification step.

34 Reaction of HMDST with $\mathrm{N}-\mathrm{H}$ unactivated aziridines 10 showed a poor selectivity, leading to a mixture of products.

35 D. Tanini, A. Grechi, L. Ricci, S. Dei, E. Teodori, A. Capperucci, New J. Chem., 2018, 42, 6077. 